\title{
Serum microRNA signature is capable of predictive and prognostic factor for SARS-COV-2 virulence
}

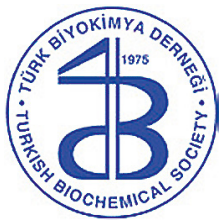

\section{Serum miRNA, SARS-COV-2 virülansı için prediktif ve prognostik faktör yeteneğine sahiptir}

https://doi.org/10.1515/tjb-2020-0520

Received October 17, 2020; accepted May 15, 2021;

published online June 18, 2021

\section{Abstract}

Objectives: Coronavirus disease 2019 (COVID-19) is a kind of viral pneumonia which is caused by severe acute respiratory syndrome coronavirus 2 (SARS-CoV-2). MicroRNAs (miRNA) are small non-coding RNAs consisting of 19-25 nucleotides and play a role in post-transcriptional gene regulation. We have focused on serum expression levels of microRNA (miRNA) a novel concept of in host-virus interactions. MicroRNA expression profiles were investigated in serum samples of COVID-19 patients.

Materials and methods: The samples were collected from 40 patients diagnosed with COVID-19 patients and from 10 healthy controls. Expression profile of 20 miRNAs were

\footnotetext{
*Corresponding author: Aydın Demiray, Department of Medical Genetics, School of Medicine, Pamukkale University, Denizli, Turkey, Universite Avenue Number: 11 Pamukkale, 20160, Denizli, Turkey, E-mail: ademiray@pau.edu.tr. https://orcid.org/0000-0002-33430184

Tuğba Sarı, Department of Infectious Diseases and Clinical Microbiology, School of Medicine, Pamukkale University, Denizli, Turkey, E-mail: tsari@pau.edu.tr

Ahmet Çalışkan, Department of Microbiology, School of Medicine, Pamukkale University, Denizli, Turkey, E-mail: acaliskan@pau.edu.tr Rukiye Nar, Department of Biochemistry, School of Medicine, Pamukkale University, Denizli, Turkey, E-mail: rnar@pau.edu.tr Levent Aksoy, Department of Microbiology, Denizli Health Hospital, Denizli, Turkey, E-mail: drlaksoy@gmail.com

İsmail Hakkı Akbubak, Department of Internal Medicine, Medical Intensive Care Unit, School of Medicine, Pamukkale University, Denizli, Turkey, E-mail: iakbudak@pau.edu.tr
}

examined using a quantitative real-time polymerase chain reaction (qPCR).

Results: Statistically significant expression level differences $(\mathrm{p}<0.05)$ were detected in nine miRNAs in COVID-19 patients and healthy controls. 7 miRNAs (hsa-let-7d, hsa-miR-17, hsa-miR-34b, hsa-miR-93, hsa-miR-200b, hsa-miR-200c, hsa-miR-223) expression levels were found to be significantly decreased and the expression levels of 2 miRNAs (hsa-miR-190a and hsa-miR-203) significantly increased respect to healthy controls.

Conclusions: We expect that a miRNA profile can be beneficial for the diagnosis of the COVID-19. Our result revealed that the increase in hsa-miR-190a level may be a prognostic factor related to the COVID-19 disease.

Keywords: COVID-19; hsa-miR-190a; miRNA; SARS-CoV-2; serum.

Öz

Amaç: Koronavirüs hastalığı 2019 (COVID-19), şiddetli akut solunum sendromu koronavirüs 2'nin (SARS-CoV-2) neden olduğu bir tür viral pnömonidir. MikroRNA'lar (miRNA), 19-25 nükleotitten oluşan ve transkripsiyon sonrası gen düzenlemesinde rol oynayan küçük kodlanmayan RNA'lardır. Serum mikroRNA'ların (miRNA) ekspresyon seviyeleri ile Konak-virüs etkileşimlerinde arasındaki ilişkiye odaklandık. COVID-19 hastalarının serum örneklerinde MicroRNA ekspresyon profilleri araştırıldı.

Gereç ve Yöntem: : COVID-19 tanısı konan 40 hastadan ve 10 sağlıklı kontrolden serum örnekleri toplandı. Yirmi miRNA'nın ekspresyon profili, gerçek zamanlı polimeraz zincir reaksiyonu (qPCR) kullanılarak araştırıldı. 
Bulgular: COVID-19 hastalarında ve sağlıklı kontrollerde dokuz miRNA'da istatistiksel olarak anlamlı ekspresyon seviyesi farklılıkları $(p<0.05)$ tespit edildi. 7 miRNA'nın (hsa-let-7d, hsa-miR-17, hsa-miR-34b, hsa-miR-93, hsa-miR-200b, hsa-miR-200c, hsa-miR-223) ekspresyon seviyeleri azalır iken 2 miRNA'nın (hsa-miR-190a ve hsamiR-203) ekspresyon seviyeleri sağlıklı kontrollere göre önemli istatistiksel olarak anlamlı derece de artmıştır. hsa-miR-190a COVID-19 ağır, orta ve hafif hasta grubu içinde de istatistiksel olarak anlamlı derecede gruplar arasında anlamlı farklılık göstermektedir. Ağır hasta grubunda ekspresyon seviyesi en yüksektir.

Sonuçlar: Bu miRNA profilinin COVID-19'un teşhisi için faydalı olabileceğini umuyoruz. Sonucumuz hsa-miR-190a seviyesindeki artışın COVID-19 hastalığı ile ilgili prognostik bir faktör olabileceğini ortaya koydu.

Anahtar Kelimeler: SARS-CoV-2; Covid-19; miRNA; serum; hsa-miR-190a.

\section{Introduction}

In December 2019, unidentified cases of pneumonia occurred in Wuhan, China's Hubei province. The coronavirus-2019 (2019-nCoV) was identified as the cause of the cases [1]. Since the corona virus has a serious zoonotic potential, the first cases were associated with the Huanan seafood market where animal contact was possible [1]. Serious Acute Respiratory Syndrome-Corona Virus-2 (SARS-CoV-2) caused pneumonia is contagious. Therefore, The World Health Organization (WHO) named the disease as COVID-19 (CoronaVirus Disease 2019). On March 11, the WHO declared the COVID-19 outbreak as a pandemic [2]. The main symptoms of COVID-19 are fever, cough, fatigue, slight dyspnoea, sore throat, headache, conjunctivitis and gastrointestinal issues.

Realtime PCR is used as a diagnostic tool using nasal swab, tracheal aspirate or bronchoalveolar lavage samples. Computed tomography findings are important for both diagnosis and follow-up. Although most patients have mild symptoms and good prognosis, COVID-19 can cause serious complications such as pneumonia, acute respiratory distress syndrome, multiple organ failure, sepsis, and death [3]. To date, there is no evidence of any effective treatment for COVID-19. Successful treatment of severe and critical cases is very important to reduce complications and mortality [3]. Therefore, it is very important to find factors related to disease severity and prognosis in clinical practice. Some risk factors such as diabetes, hypertension, advanced age, smoking, immunosuppression, chronic lung disease and chronic kidney failure have been identified in COVID-19 patients, and patients with one or more of these risk factors have been shown to have higher mortality and morbidity than those who does not [3]. SARS-CoV-2, which causes acute respiratory disease called COVID-19, is a new betacoronavirus. Apart from the new member of coronaviruses, which are zoonotic pathogens, SARS-CoV-2, SARS-CoV, MERS-CoV, HKU1, NL63, OC43 and 229E can also infect humans and cause respiratory infections. SARS-CoV-2, the cause of SARS epidemic between 2002 and 2003, is genetically $80 \%$ similar to SARS-CoV, $50 \%$ similar to MERS-CoV, and the similarity to bat's coronaviruses is $\sim 96 \%$ [2]. SARS-CoV-2 is a single-stranded positivesense RNA virus and has a $30 \mathrm{~kb}$ genome containing 14 open reading frame (ORFs) regions. The Covs genome encodes replicase (ORF1a and ORF1ab), structural proteins (spike, nucleocapsid, membrane, and envelope), and accessory proteins (ORF 3a, ORF 3b, ORF6, ORF 7a, ORF 7b, ORF 8a, ORF 8b, and ORF 9b) [4]. Spike (S) protein of the coronaviruses facilitates viral entry into target cells. The introduction begins with the binding of the surface unit $\mathrm{S}$ of the $S$ protein to a cellular receptor that facilitates viral binding to target cells. It consists of S1/S2 subunit of S protein and S2 subunit. Fusion of viral and cellular membranes is performed by the S2 subunit [5]. SARS-S binds to angiotensin converting enzyme 2 (ACE2) as the input receptor and uses cellular serine protease TMPRSS2 to prepare S protein. The molecular mechanism of the SARS-S/ ACE2 activation pathway has been described and the effectiveness of ACE2 has been found to play a key role in SARS-CoV permeability. SARS-CoV-2, which binds to the ACE2 receptor found in human lung type 2 alveolar cells, enters the cell through the endosome [6].

MicroRNAs are small non-coding RNAs consisting of 19-25 nucleotides [7]. In the nucleus, the precursor is synthesized as miRNA (pri-miRNA) and cut into the drosha enzyme and passes into the cytoplasm of 60-70 nucleotides in length. As a result of cutting with the pre-miRNA dicer enzyme that passes into the cytoplasm, it reaches the mature miRNA form of 19-25 nucleotides. miRNA plays a role in post-transcriptional gene regulation [8]. It forms the miRNA-induced silencing complex (RISC) and blocks the expression of mRNAs through Argonaute [8]. As a result, since miRNA is transported from the cell to the extracellular matrix of the cell by exocytosis or exosomes, the level of expression at the serum level will be affected equally. miRNAs coming out of the cell with exocytosis can reach the general circulation from the intercellular fluid [9]. This process/functioning generates a relationship between miRNAs and molecular pathogenesis of the diseases [7]. In 
addition, miRNAs have a potential to be a biomarker in the definition of diseases [7].

In our study, patients were separated into 3 groups first group is patients with SARS-CoV-2 PCR positive test, second group is patients with being COVID-19 clinically compliant and PCR negative, last group is the control group includes healthy volunteers with negative PCR testing and have not any clinical signs and comorbidities were compared in the regard of serum miRNA expression levels. First of the stages was investigation of any significant difference in serum miRNA expression levels between the patient group and the healthy group. The second of stages was investigation of relationship with viral infection that depending on increase or decrease in serum miRNA expression levels in the patient group. At the same time, it was investigated whether there was a statistically significant difference between the serum miRNA expression levels of the patient group compared to the mild, severe, and critical.

\section{Material and method}

\section{Collection of patient samples}

A prospective, cross-sectional interventional case series study was designed. The study was carried out in accordance with the Helsinki Declaration. The study protocol was approved by the Ethics Committee (60116787-020/28661). Written informed consent was obtained from all patients included in the study over the age of 18 between 03 and 04/2020; 20 patients diagnosed with SARS-CoV-2 positive detection by RT-PCR test in the nasopreneal swab sample, the other 20 patients had PCR negative but being clinically compliant COVID-19 and 10 healthy controls were with PCR negative and had any comorbid disease. A total of 50 patients were included in the study. RT-PCR test was performed with tracheal aspiration and nonbronchoscopic BAL from four patients who were followed by intubation. Typical computed tomography findings in individuals, COVID-19 were ground-glass opacities, particularly on the peripheral and lower lobes, and the tests were repeated on patients with bilateral multiple lobular and subsegmental areas of consolidation and patients with no virus detected by RT-PCR. COVID-19 patients were evaluated as mild, severe, and critical according to the clinical presentation based on the definitions in the "COVID-19 Diagnosis and Treatment Guide" published by the Turkish Ministry of Health [10]. Mild illness is defined with characteristics such as fever, cough, sore throat, nasal congestion, and muscle or joint pain, with or without mild pneumonia together with a respiratory rate $<30 / \mathrm{min}$ and an $\mathrm{O}_{2}$ saturation above $90 \%$ while breathing room air. Severe illness is characterized with widespread findings of pneumonia in radiological examinations like chest radiography or computed tomography. Critical illness describes the requirement of the intensive care unit.

RT-PCR protocol: Bio-Speedy ${ }^{\circledR}$ COVID-19 RT-qPCR Detection Kit Version 2 was used in the study. VNAT (viral nucleic acid buffer) was used as the extraction kit. The RdRp gene targeted Wuhan-RdRp oligonucleotide set containing SARS-CoV-2 (2019-nCoV) detection (RdRp gene) (FAM) and Internal control (IC) (RNase P gene) (HEX) was used. Primescript RT master mix containing DNA polymerase, dNTP mix, reaction buffer, reverse transcriptase, and ribonuclease inhibitor were used. The reaction was programmed into 45 cycles, $15 \mathrm{~min} 1$ cycle at $45^{\circ} \mathrm{C}, 3 \min 1$ cycle at $95^{\circ} \mathrm{C}, 5 \mathrm{~s}$ at $95^{\circ} \mathrm{C}$, and $35 \mathrm{~s}$ at $55^{\circ} \mathrm{C}$. Then, $100 \mu \mathrm{l}$ of sample was transferred to the tube containing $100 \mu \mathrm{l}$ of viral nucleic acid buffer (vNAT). The tube containing sample fluid and vNAT was vortexed for $10 \mathrm{~s}$ and nucleic acids were extracted. For each sample, a mixed reaction solution containing $5 \mu \mathrm{l} \mathrm{RdRp} \mathrm{gene} \mathrm{targeted} \mathrm{Wuhan-}$ RdRp oligonucleotide and $10 \mu$ Prime Script Mix was prepared. After vortexing, $5 \mu \mathrm{l}$ of fluid taken from the tube containing the sample and vNAT was transferred to the PCR tube containing $5 \mu \mathrm{l}$ of oligonucleotide and $10 \mu \mathrm{l}$ of prime. PCR tube containing $5 \mu \mathrm{l}$ of extracted nucleic acid and $15 \mu \mathrm{l}$ of mixed reaction solution was studied on the Qiagen Rotorgene $Q$ device. In approximately $90 \mathrm{~min}$, the PCR procedure was completed and the proliferation curves obtained were examined. Non-sigmoidal curves were recorded as negative. Threshold level is set to 0.02 for Qiagen Rotorgene Q. "Dynamic Tube" option is activated and "Outlier Removal" option is set to 0 . The results were recorded as the number of threshold cycles (Cq), negative if $\mathrm{Cq} \geq 40$, and positive if $\mathrm{Cq}<40$.

\section{miRNA isolation}

Obtained serum samples were treated with $1 / 5$ of qiazol and miRNA isolation was performed using the miRNeasy serum/plasma kit (cat: 217184 Hilden, Germany). The obtained miRNAs are made by spectrophorometric measurements. It was stored at $-20^{\circ} \mathrm{C}$.

\section{cDNA synthesis}

After the isolation of miRNAs was converted to cDNA using abm miRNA cDNA synthesis kit which poly (A) polymerase tailing (cat: G903 Richmond, Canada). Then spectrophotometric measurement was made and stored at $-20^{\circ} \mathrm{C}$.

\section{Measurement of miRNA expression levels}

qPCR was performed using Eva-Green miRNA qPCR Master Mix (ABM, Richmond, Canada) in accordance with the experimental protocol. The serum miRNAs (hsa-let-7b, hsa-let-7d, hsa-miR-17, hsa-miR-34a, hsa-miR-34b, hsa-miR-92, hsa-miR-93, hsa-miR-141, hsa-miR-145, hsamiR-190a, hsa-miR-200a, hsa-miR-200b, hsa-miR-200c, hsa-miR-203, hsa-miR-223, hsa-miR-369, hsa-miR-410, hsa-miR-411, hsa-miR-452, hsa-miR-548v, hsa-miR-662) expression levels were determined for each patient, and for the control sample using miRNA qPCR Master Mix (ABM, Richmond, Canada) Kit. miRNAs target gene expressions were analyzed in the presence of U6 reference genes in the Bio-rad cfx connect (Bio-Rad, California, USA). All qPCR reactions were performed in duplicate to calculate the average values. The cycle threshold (CT) was determined for each miRNA, and a control gene (U6). The relative abundance of each miRNA transcript was then determined using delta CT method. The delta CT was used to evaluate the relative expression levels of miRNA genes in the samples of patients and healthy controls. 


\section{Statistical analysis}

Using CT values in the patient and healthy control groups, the increase or decrease ratio of expression levels serum miRNA genes and the U6 gene were calculated according to the following formula.

$$
2^{-\Delta \Delta C \mathrm{~T}} \text { where } \Delta \mathrm{CT}=\mathrm{CT} \text { target gene }-\mathrm{CT} \text { reference gene }
$$

All data is evaluated parameters using the program with Graphpad Prism 7.0 version, the association between miRNA's among clinicopathological and demographic factors was determined by analysis of variance (Bonferroni's multiple comparisons test). Receiver operating characteristic (ROC) curve was blotted between investigated groups to detect the sensitivities and the specificities for the miRNAs and their diagnostic efficacy [11]. Correlations between investigated miRNAs were carried out using unpaired t-test was applied.

\section{Result}

\section{Clinopathologies of patients}

There are 20 patients who have been diagnosed with SARS-CoV-2 in the RT-PCR test and diagnosed with COVID-19, and the other 20 patients who did not detect viruses by RT-PCR although they were clinically coherent. The average age of the patients was 55 (range 32-99). The mean age of 10 healthy controls was 36 years old (26-46). Eight female and 12 male patients were tested positive in COVID-19 PCR analysis. Nine female and 11 male patients were tested negative in COVID-19 PCR analysis and healty control were consist of 6 female and 4 male individuals. While 13 of COVID-19 PCR positive patients receive only plaquenil treatment, 7 of them receive additional treatment with plaquenil, while 5 of PCR negative patients receive only plaquenil treatment and 15 receive additional treatment with plaquenil. None of the patient had additional diseases. Four of the 20 patients who were diagnosed with positive SARS-CoV-2 by RT-PCR test and diagnosed with COVID-19 were followed up in the intensive care unit, 9 of them had mild clinical and 7 of them had severe clinical complications. Ten patients who were diagnosed with negative SARS-CoV RT-PCR test but computed tomography diagnosed with COVID-19 had pneumonia in radiologic imaging and followed up in the intensive care unit and 10 of them had severe clinical complications. While 10 of COVID-19 positive patients had pneumonia in their computed tomography findings, 10 of them did not. Typical computed tomography findings in individuals with COVID-19 were ground-glass opacities, particularly on the peripheral and lower lobes, and bilateral multiple lobular and subsegmental areas of consolidation (Table 1).
Table 1: Clinicopathologic characteristics of patients.

\begin{tabular}{llrrr}
\hline Characteristics & Sub type & \multicolumn{2}{c}{ Patients $(\mathrm{n}=40)$} & $\begin{array}{r}\text { Healty } \\
(\mathrm{n}=10)\end{array}$ \\
\cline { 3 - 4 } & & pcr (+) & pcr (-) & \\
\hline Age & $\leq 55$ & 11 & 11 & 6 \\
\multirow{4}{*}{ Gender } & $>55$ & 9 & 9 & 4 \\
\multirow{4}{*}{ Status } & Male & 8 & 11 & 4 \\
& Female & 4 & 9 & 6 \\
\multirow{3}{*}{ Treatment } & ICU & 9 & 10 & \\
& In-patient & 7 & - & \\
& Asymptomatic & & & \\
CT & Plaquenil & 13 & 5 & \\
& Plaquenil (+) & 7 & 15 & \\
& & & & \\
& Pneumonia & 10 & 20 & \\
& Non- & 10 & - & \\
\hline
\end{tabular}

Table 2: Mean expression level of serum miRNA.

\begin{tabular}{lrrrr}
\hline miRNA & Healthy volunteers & Patients & p-Value \\
\hline hsa-let-7d & $0.4651 \pm 0.06444$ & $0.1894 \pm 0.02926$ & 0.0001 \\
hsa-miR-17 & $0.6346 \pm 0.0718$ & $0.2832 \pm 0.331$ & $<0.0001$ \\
hsa-miR-34b & $1.721 \pm 0.1044$ & $0.7365 \pm 0.1412$ & 0.0013 \\
hsa-miR-93 & $3.019 \pm 0.2684$ & $0.8622 \pm 0.2152$ & $<0.0001$ \\
hsa-miR-200b & $0.64 \pm 0.1341$ & $0.2204 \pm 0.04491$ & 0.0005 \\
hsa-miR-200c & $0.5573 \pm 0.103$ & $0.0407 \pm 004278$ & $<0.0001$ \\
hsa-miR-223 & $3.546 \pm 0.341$ & $1.309 \pm 0.2485$ & 0.0001 \\
hsa-mir-190a & $2.345 \pm 0.4324$ & $4.067 \pm 0.2613$ & 0.0038 \\
hsa-miR-203 & $0.881 \pm 0.2553$ & $2.499 \pm 0.2527$ & 0.0033 \\
\hline miRNA & Critical & Severe & Mild & p-Value \\
\hline hsa-let-7d & 0.2485 & 0.1738 & 0.127 & 0.0039 \\
hsa-miR-200b & 0.2906 & 0.2243 & 0.1037 & 0.0402 \\
hsa-miR-223 & 1.576 & 1.388 & 0.7426 & 0.0039 \\
hsa-mir-190a & 4.324 & 4.57 & 3.646 & 0.0004 \\
\hline
\end{tabular}

\section{Serum miRNA expression levels}

In this study, 20 miRNA's (hsa-let-7b, hsa-let-7d, hsamiR-17, hsa-miR-34a, hsa-miR-34b, hsa-miR-92, hsamiR-93, hsa-miR-141, hsa-miR-145, hsa-miR-190a, hsamiR-200a, hsa-miR-200b, hsa-miR-200c, hsa-miR-203, hsa-miR-223, 369, hsa-miR-410, hsa-miR-411, hsa-miR-452, hsa-miR-548v, hsa-miR-662) expression levels were investigated serum samples (Figure 1). By plotting the ROC, the diagnostic efficacy were determined using the calculated $p$ value and confidence interval (Figure 2).As a result of this research, expression levels of 7 miRNA's (hsa-let-7d, hsa- 
miR-17, hsa-miR-34b, hsa-miR-93, hsa-miR-200b, hsamiR-200c, hsa-miR-223) were found to be significantly decreased and 2 miRNAs (hsa-miR-190a and hsa-miR-203) were found significantly increased compared to healthy group (Table 2, Figure 3).

\section{The effect of miRNA expressions on clinic}

In this study, we show that COVID-19 patients serum 9 miRNA's expression levels is significantly higher than healthy group (hsa-let-7d, hsa-miR-17, hsa-miR-34b, hsa-miR-93, hsa-miR-200b, hsa-miR-200c, hsa-miR-223, hsa-miR-190a and hsa-miR-203). The COVID 19 with PCR
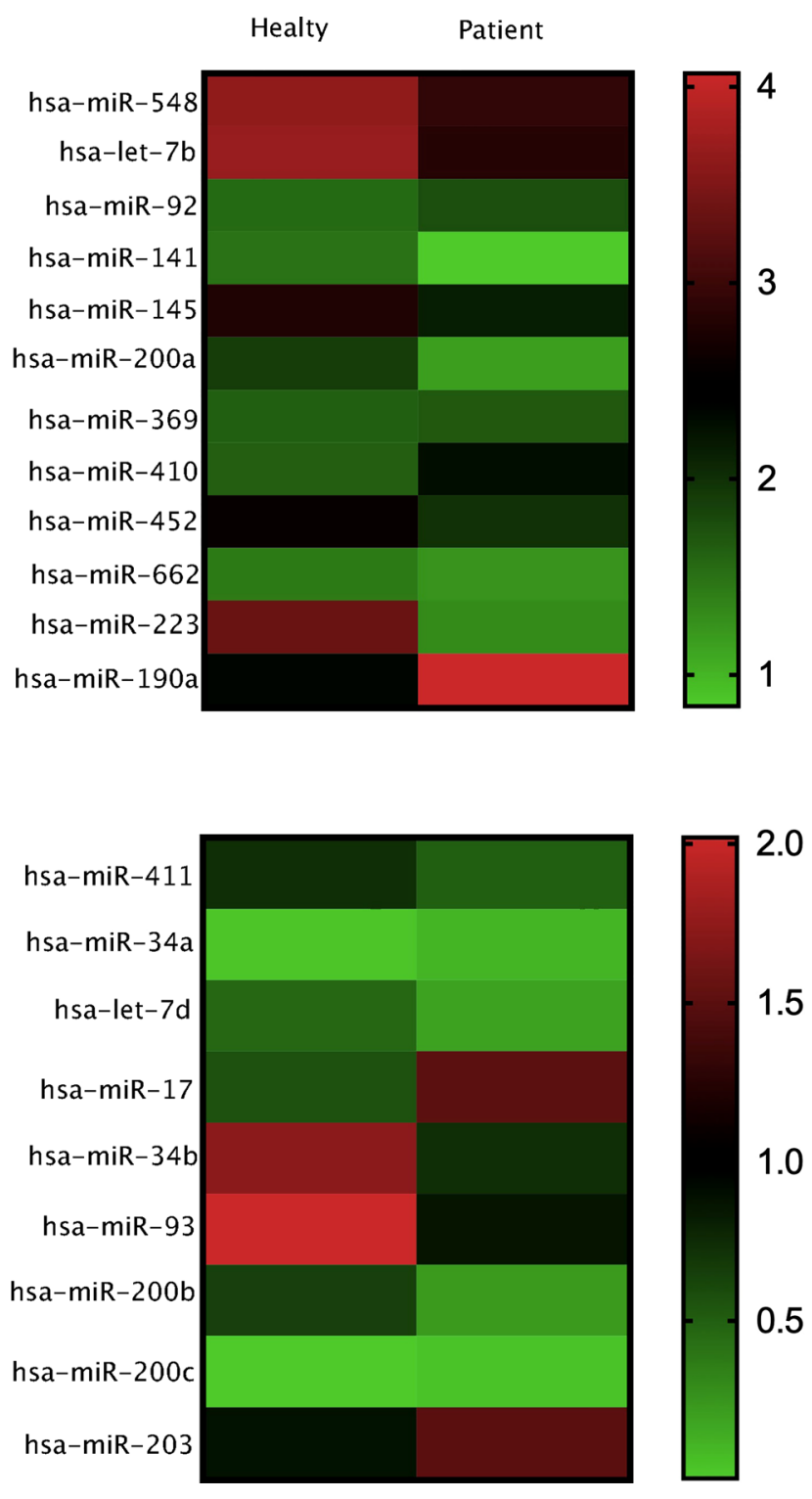

Figure 1: The heatmap of the differentially expressed miRNAs. positive patients all miRNA's serum expression levels is no statistically significantly different the COVID 19 with PCR negative patients. A statistically significant difference was found between the expression levels of hsa-let-7d, hsa-miR-190a, hsa-miR-200b and hsa-miR-223 between the patient groups with mild, severe, and critical clinicals (Figure 4). Interestingly, these four miRNAs, which are lowexpressed within the healthy group, have higher mean miRNA expression levels among patients with critically clinical. In terms of treatment option, there was no statistically significant difference in the levels of miRNA expression between the groups of patients receiving plaquenil and additional treatment with plaquenile. There was no statistically significant difference between in the levels of miRNA expression between patients diagnosed with pneumonia and patient diagnosed without pneumonia. In this study, 9 miRNAs (hsa-let-7d, hsa-miR-17, hsa-miR-34b, hsa-miR-93, hsa-miR-200b, hsa-miR-200c, hsa-miR-223, hsa-miR-190a and hsa-miR-203) were analysed according to the clinical features of the patients. As a result, no statistically significant difference was found between the COVID-19 positive and COVID-19 PCR negative groups between in these miRNA expression levels. Critical clinical patients is a statistically significant difference than mild and severe clinical patients at the hsa-miR-190a expression level. Critical clinical patients is a statistically significant difference than mild clinical patients at the hsa-let-7d, hsa-miR200b and hsa-miR-223 expression levels (Figure 4).

\section{Discussion}

There are publications in the literature regarding miRNA expression levels of SARS-CoV-2 infected cells. However, there is no study comparing miRNA levels of patients serums diagnosed with SARS-CoV-2 and serum miRNA levels of healthy individuals. Our study is the first article demonstrating the serum miRNAs profile of patients diagnosed with SARS-CoV-2 and the healthy individuals. The viral genome with internalization in the cell were targeted by the host's miRNAs in the normal process and it cuts from where it is complementary to the viral genome [12]. However, this works just the opposite in RNA viruses. The host's miRNAs help viral replication [12]. In addition, if viral genome-specific sequences are recognized after replication, RNA viruses can escape the intracellular defense by changing the region as a result of mutation [12]. Another way is that replication continues as a result of reducing the expression levels of miRNA with viral genome-specific sequences [12]. In literature, it is reported 
hsa-let-7d

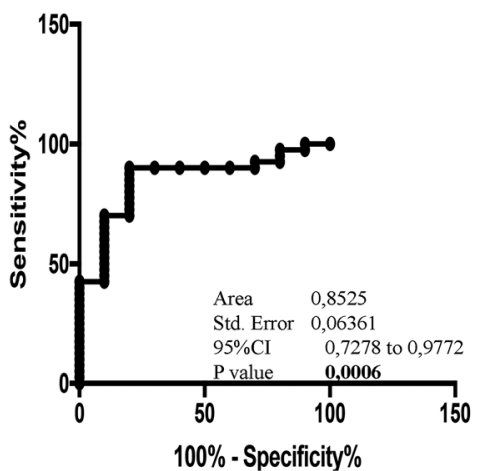

hsa-miR-93

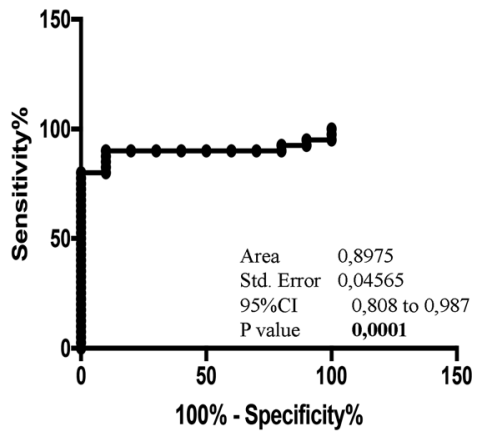

hsa-miR-223

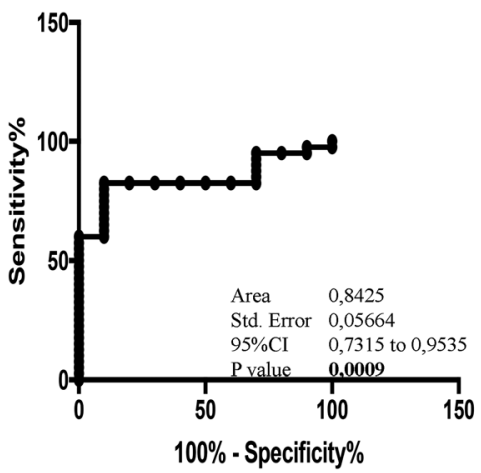

hsa-miR-17

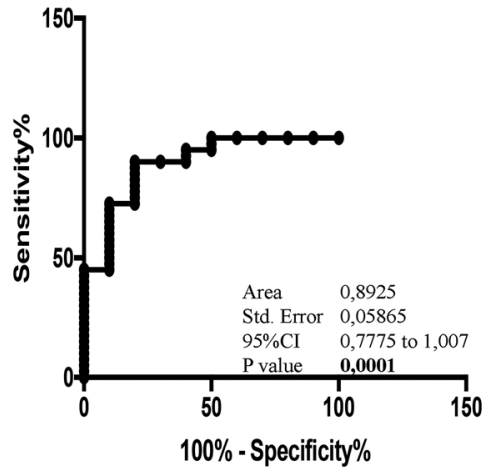

hsa-miR-200b

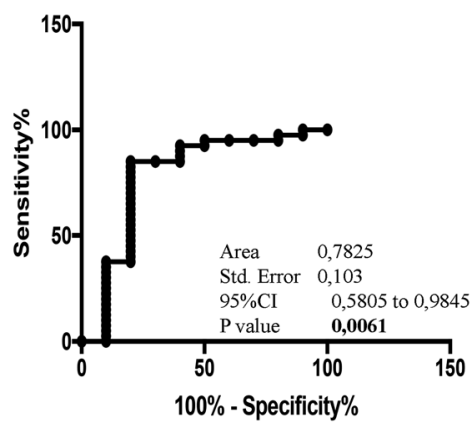

hsa-miR-190a

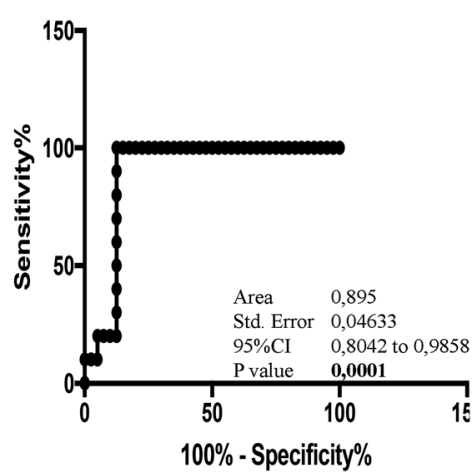

hsa-miR-34b
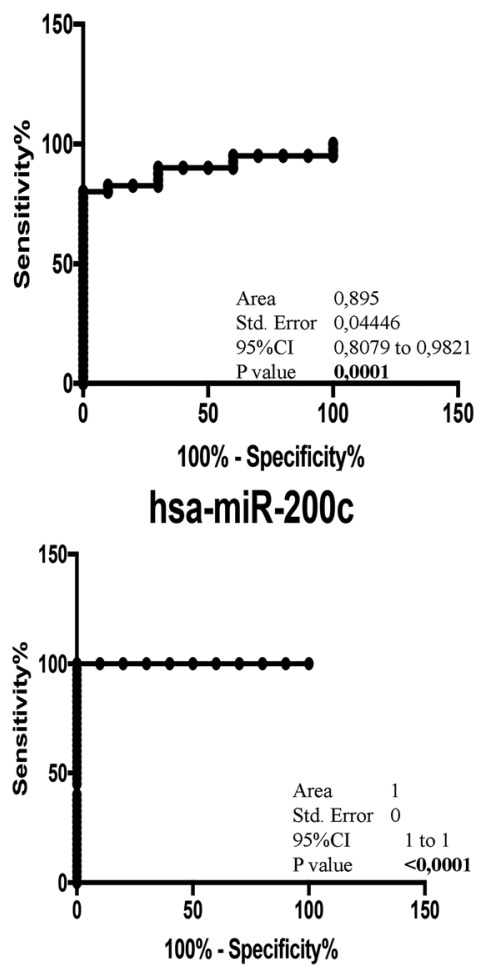

hsa-miR-203

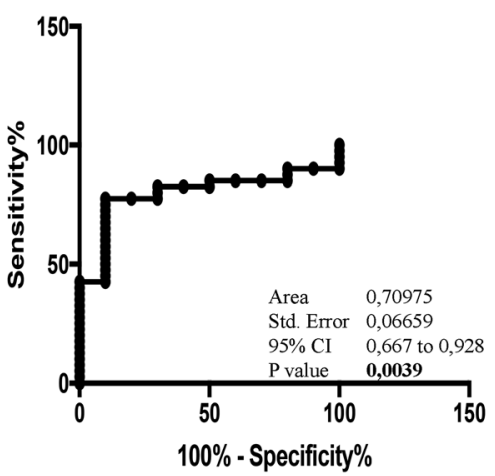

Figure 2: Receiver operating characteristic (ROC) curve was blotted between investigated groups to detect the sensitivities and the specificities for the miRNAs.

that hsa-miR-17 has targeted to viral S, N, Orf1a, M and E proteins. It was suppressed during viral replication in cell [8, 12]. Li Q (2017) and Mallick B. (2009) reported that they were associated with ACE 2 for miR-200c, miR-200b and miR-93 [12, 13]. S protein binds to ACE 2 protein to induce membrane fusion. Viral $S$ protein reduces ACE 2 expression $[12,13]$. Mallic [12] showed that intracellular levels of miR-93 and miR-200b were downregulated. Li [13] showed that the decrease in the expression of miR-200c caused an increase in ACE 2 expression. As a result of this miR-200c expression is also expected to decrease. As the viral replication continues, strong chemokine release occurs in the microenvironment and in the cell. Chemokine receptor 1 (CCR 1), which responds to these chemokines, has an important role in pulmonary fibrosis in the lung injury model [14]. One of the target of miR-223 is CCR1 [15]. Increased expression of CCR 1 has been reported to increase in pulmonary fibrosis [12]. Mallic [12] reported reduced miR-223 expression in host cells. In addition, miR-223, the target of viral $\mathrm{N}$ protein, was reported to be decreased. SARS-CoV-2 virus has been reported to target cells with CD $34(+)$ ACE $2(+)$ as targets [15]. It was reported that decreased as corelated the expression levels of let-7d with CD34 in viral infection [12]. Min [16] reported a 

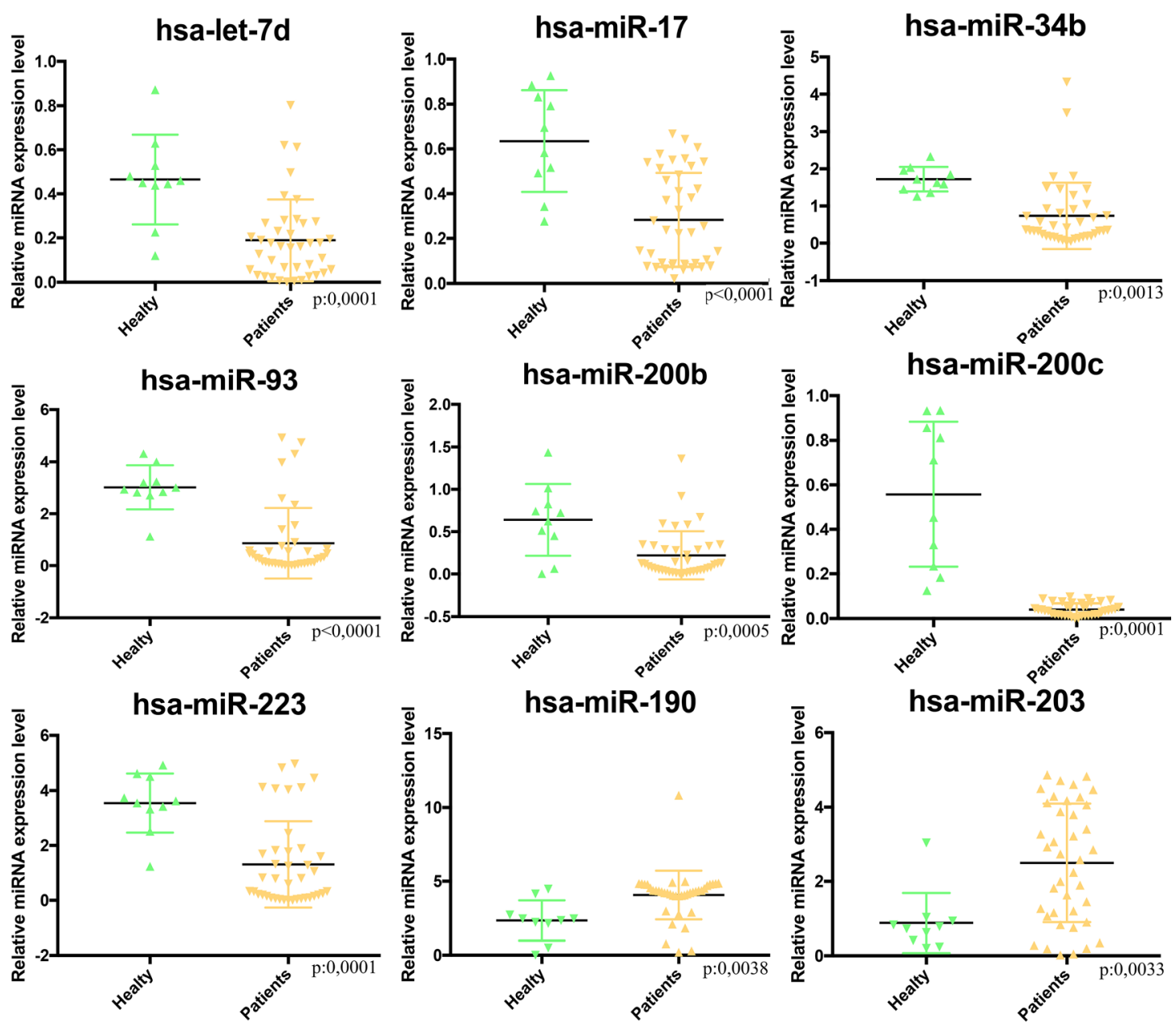

Figure 3: Relative expression levels of nine miRNA in serum from healthy and patients.

decrease in let-7d expression in idiopathic lung fibrosis. In this study, which is done by respiratory syncytial virus Inchley [17] reported that miR-34b expression level decreased. RSV is also an RNA virus, and it can be a pneumonia agent. In our study, miRNAs whose serum expression level decreased compared to healthy patients (hsa-let-7d, hsa-miR-17, hsa-miR-34b, hsa-miR-93, hsa-miR-200b, hsa-miR-200c, hsa-miR-223) in the literature overlaps with miRNAs whose expression in the cell decreases as a result of viral infection. Demirci [18] reported that they were complementary with miR-34b S protein and ORF1ab region according to viral targeting they determined using computer program with SARS-CoV-2. Our results proof the Demirci et al.'s study in vitro. William [19] showed that the expression of miR-203 increased in his study with Sendai virus, an RNA virus, and played an important role in the regulation of the Interferon Inducible Regulator gene (IFIT1/ISG56) in this increase. Intracellular patterns are similar among RNA viruses. In addition, Jiang [20] attributed the increase of Krüppel-like factor (KLF15) due to hypoxia to miR-190a. As a result, it has been shown that increased miR-190a level is a chronic pulmonary disease $(\mathrm{COPH})$ biomarker [20]. In our study, the fact that the patients had 14 critical and 17 severe clinicals support the increase in miR-190a in terms of disease pathogenesis. The expression level of miR-190a in patients with critical and severe clinical is higher than the group of patients with mild clinical (critical vs. severe p:0.0196, critical vs. mild $\mathrm{p}<0.0001$, severe vs. mild p: 0.0396). In this case, miR-190a may be a prognostic factor in relation to COVID-19 disease. It can be used in the clinic as a biomarker for the process of the disease. In our study we demonstrated that decrease serum hsa-let-7d, hsa-miR-17, hsa-miR-34b, hsa-miR-93, hsa-miR-200b, hsa-miR-200c, hsa-miR-223 levels and increase serum hsa-miR-203, hsa-miR190a levels. In addition, we have unveiled that the increase in hsa-miR-190a level and the fact that it is less in patients with mild clinical may be a prognostic factor related to the disease. Also, the 

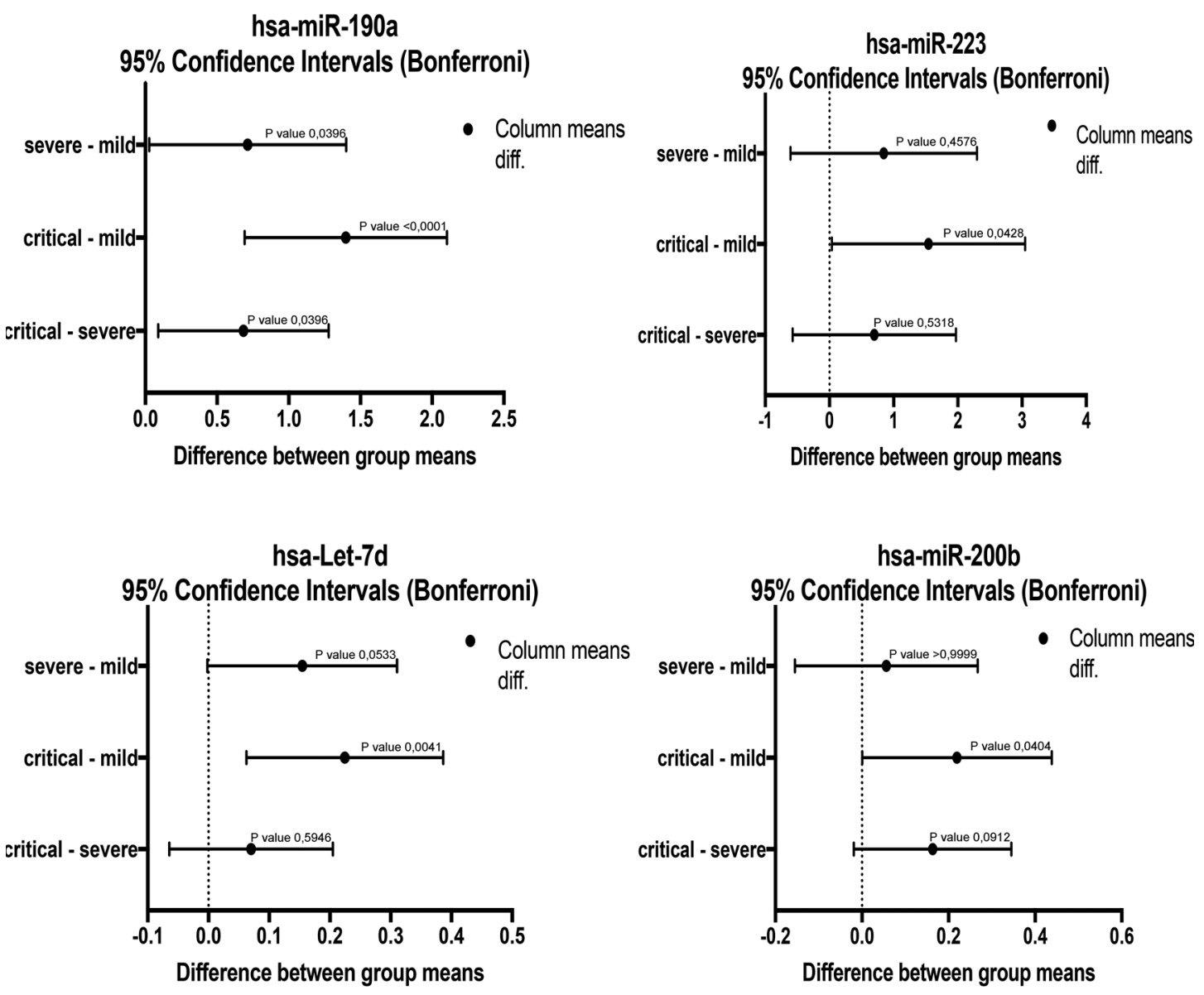

Figure 4: Four miRNA's clinicopathological analysis of variance (Bonferroni's multiple comparisons test).

serum expression levels of all 9 miRNAs are nearly equally between COVID-19 PCR positive and COVID-19 PCR negative patients. The PCR test used to diagnose COVID-19 can be false negative or false positive occasionally. In addition to the PCR method, antibody test is applied in the clinic. In parallel with this, this results we have propose to diagnose COVID-19, we expect that a miRNA panel can benefacial diagnose. We, also, predict that it might be used as a prognostic factor for miR-190a in the follow-up of COVID-19 patients. The limitations of our study can be eliminated with a comprehensive and wider miRNAs panel. Our study is a disadvantage with a very narrow group. This study needs to be confirmed with a larger patient population and larger miRNA panel. We have uncovered diagnostic and prognostic miRNAs related to COVID-19 disease. Afterthought, we assume that nano-carriers inhalators with miRNAs might be used COVID-19 treatment. Thus, a response that can be generated in the cellular by blockage of viral replication might be presented as a more effective treatment option.

\section{References}

1. Huang C, Wang Y, Li X, Ren L, Zhao J, Hu Y, et al. Clinical features of patients infected with 2019 novel coronavirus in Wuhan, China. Lancet 2019 2020;395:497-506.

2. Hirano T, Murakami M. COVID-19: a new virus, but a familiar receptor and cytokine release syndrome. Immunity 2020;52:1-3.

3. Zheng Z, Peng F, Xu B, Zhao J, Liu H, Peng J, et al. Risk factors of critical \& mortal COVID-19 cases: a systematic literature review and meta-analysis [published online ahead of print, $2020 \mathrm{Apr} 23$ ]. J Infect 2020;S0163-4453:30234-6.

4. Huang S-H, Lee T-Y, Lin Y-J, Wan L, Lai C-H, Lin C-W. Phage display technique identifies the interaction of severe acute respiratory syndrome coronavirus open reading frame 6 protein with nuclear pore complex interacting protein NPIPB3 in modulating Type I interferon antagonism. J Microbiol Immunol Infect 2017;50:277-85.

5. Asselta R, Maria Paraboschi E, Mantovani A, Duga S. ACE2 and TMPRSS2 variants and expression as candidates to sex and country differences in COVID-19 severity in Italy. Aging 2020;11:10087-98.

6. Hoffmann M, Kleine-Weber H, Schroeder S, Kruger N, Herrler T, Erichsen S, et al. SARS-CoV-2 cell entry depends on ACE2 and TMPRSS2 and is blocked by a clinically proven protease inhibitor. Cell 2020;181:271-80. 
7. Fulzele S, Sahay B, Yusufu I, Lee TJ, Sharma A, Kolhe R, et al. COVID-19 virulence in aged patients might be impacted by the host cellular microRNAs abundance/profile. Aging Disease 2020; 3:509-22.

8. Tahamtan A, Inchley CS, Marzban M, Tavakoli-Yaraki M, TeymooriRad $M$, Nakstad B, et al. The role of microRNAs in respiratory viral infection: friend or foe? Rev Med Virol 2016;26:389-407.

9. Mustafa H, Ercan K, Güzeloglu A. MikroRNA Biyogenezi Atatürk Üniversitesi. Vet. Bil. Derg. 2015;10:211-8.

10. https://covid19bilgi.saglik.gov.tr/tr/covid-19-rehberi.html [Accessed Jul 2020].

11. Zweig MH, Campell G. Receiver-operating characteristics (ROC) plots: a fundamental evaluation tool in clinical medicine. Clin Chem 1993;39:561-77.

12. Mallick B, Ghosh Z, Chakrabarti J. MicroRNome analysis unravels the molecular basis of SARS infection in bronchoalveolar stem cells. PLoS One 2009;11:11-2.

13. Liu Q, Du J, Yu X, Xu J, Huang F, Li X, et al. miRNA-200c-3p is crucial in acute respiratory distress syndrome. Cell Discov 2017;3:1-17.

14. Tokuda A, Itakura $M$, Onai N, Kimura H, Kuriyama T, Matsushima K. Pivotal role of CCR1-positive llukocytes in bleomycin-induced lung fibrosis in mice. J Immunol 2000;164:2745-51.
15. Fazi F, Rosa A, Fatica A, Gelmetti V, De Marchis ML, Nervi C, et al. A minicircuitry comprised of microRNA-223 and transcription factors NFI-A and C/EBPalpha regulates human granulopoiesis. Cell 2005;123:819-31.

16. Min H, Fan S, Song S, Zhuang Y, Li H, Wu Y, et al. Plasma microRNAs are associated with acute exacerbation in idiopathic pulmonary fibrosis. Diagn Pathol 2016;135:1-7.

17. Inchley CS, Sonerud T, Fjærli HO, Nakstad B. Nasal mucosal microRNA expression in children with respiratory syncytial virus infection. BMC Infect Dis 2015;150:1-11.

18. Saçar Demirci MD, Adan A. Computational analysis of microRNA-mediated interactions in SARS-CoV-2 infection Peer. J Bioinform Genom 2020;8:1-12.

19. Buggele WA, Horvath CM. MicroRNA profiling of Sendai virusinfected A549 cells identifies miR-203 as an interferon-inducible regulator of IFIT1/ISG56. J Virol 2013;16:9260-70.

20. Jiang J, Xia Y, Liang Y, Yang M, Wen Z, Zeng X. MiR-190a-5p participates in the regulation of hypoxia induced pulmonary hypertension by targeting KLF15 and can serve as a biomarker of diagnosis and prognosis in chronic obstructive pulmonary disease complicated with pulmonary hypertension. Int J COPD 2018;13:3777-90. 